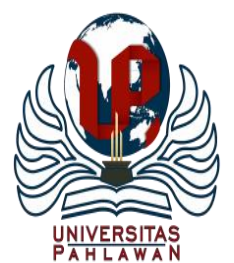

Edukatif : Jurnal Ilmu Pendidikan Volume 3 Nomor 3 Tahun 2021 Halm 1059 - 1066

EDUKATIF: JURNAL ILMU PENDIDIKAN

Research \& Learning in Education

https://edukatif.org/index.php/edukatif/index

\title{
Pemahaman Remaja Tentang Internet Sehat di Era Globalisasi
}

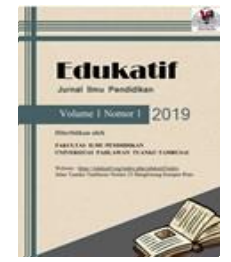

\author{
Dian Montanesa ${ }^{1 凶}$, Yeni Karneli ${ }^{2}$ \\ Universitas Negeri Padang,Indonesia ${ }^{1,2}$ \\ E-mail : dianmontanesa@gmail.com ${ }^{1}$, yenikarneli@gmail.com ${ }^{2}$
}

\begin{abstract}
Abstrak
Di era globalisasi seperti saat sekarang ini kehidupan remaja telah berubah. Remaja dan internet saat ini menjadi sangat dekat satu sama lain dan tidak dapat dipisahkan. Para remaja sudah memiliki gadget pribadi yang memudahkan mereka untuk menjalin kontak dengan dunia luar. Tujuan dari penelitian ini adalah untuk mendeskripsikan pemahaman remaja tentang internet sehat. Metode yang dilakukan dalam studi kali ini adalah metode literature research, dengan mengumpulkan berbagai teori yang relevan. Hasil penelitian ini mengungkapkan bahwa pemahaman remaja tentang internet sehat harus ditingkatkan agar tidak terjadi penyalah gunakan penggunaan internet dikalangan remaja. Implikasi dari studi kali ini adalah agar ada peran serta antara orangtua dan guru agar mampu membimbinga serta memberikan pemahaman kepada remaja pentingnya berinternet sehat dalam kehidupan sehari-hari.
\end{abstract}

Kata Kunci: Pemahaman, Internet Sehat, Remaja.

\begin{abstract}
In globalization era, teenagers life has been changed. Teens and internet become very close to each other and cannot be separated. Teenagers already have personal gadgets that make them easier to establish contact to the world wide. The purpose of this study is to describe adolescent's understanding of health internet. The method used in this study was the literature research, by collecting various relevant theories. The results of this study was to reveal the adolescent's understanding of health internet, this study shows that the understanding about health internet must be improved to decrease misuse of the internet among adolescents. The implication of this study is to bridging the participation between parents and teachers in order to be able to guide and provide understanding of healthy internet for adolescents on the surfing in everyday life.
\end{abstract}

Keywords: comprehension, health internet, teenagers.

Copyright (c) 2021 Dian Montanesa, Yeni Karneli

$\triangle$ Corresponding author

Email : dianmontanesa@gmail.com

DOI : https://doi.org/10.31004/edukatif.v3i3.509

ISSN 2656-8063 (Media Cetak)

ISSN 2656-8071 (Media Online) 


\section{PENDAHULUAN}

Kehidupan remaja saat ini yang dekat dengan internet merupakan fenomena baru yang dirasakan oleh remaja yang hidup di era globalisasi yang ditandai dengan kemajuan teknologi (Rahman 2016). Remaja masa kini memiliki hubungan yang intens dengan internet. Remaja yang pada umumnya telah memiliki smartphone atau gadget pribadi bebas mengakses jaringan internet (Widayani and Astuti 2020). Internet merupakan teknologi bermata dua yang memiliki dua sisi, yaitu sisi positif dan sisi negatif, diharapkan remaja lebih banyak memanfaatkan internet untuk hal-hal yang positif (Rahayu 2012). Tetapi pada fenomena yang ditemukan dari hasil penelitian dan observasi di sekolah menunjukkan bahwa internet dikalangan remaja banyak berdampak negatif, hal ini harus diperhatikan karena remaja merupakan penerus bangsa, jangan hanya karena internet mampu merusak remaja sehingga masa depan suatu bangsa menjadi terancam (Simangunsong 2015).

Hasil penelitian Top Ten Reviews mengungkapkan setiap detiknya 28 ribu orang mengakses situs pornografi di Internet (Ramdani 2009). Hasil penelitian dari Gallub Youth Survey yang dilakukan pada bulan Januari-Februari tahun 2003, sebanyak 1.200 responden usia 13-17 tahun tentang penggunaan internet dikalangan remaja mengungkapkan bahwa 96\% remaja menggunakan intenet untuk mengirim dan menerima email, 96\% mencari informasi, 87\% mengobrol dengan teman menggunakan layanan pesan instan, 73\% megunduh musik, 39\% mengunjungi ruang chatting, dan 31\% berbelanja online shop (Qomariyah 2009). Ketika remaja sedang mencari informasi besar peluang remaja menemukan baik disengaja maupun tidak sengaja gambar, situs, video, pornografi dan video asusila. Hasil penelitian dari PBB yang berjudul "Keamanaan Penggunaan Media Digital Pada Anak dan Remaja di Indonesia" melibatkan 400 responden remaja berusia 10-19 tahun di Indonesia membuktikan bahwa 98\% remaja mengaku tahu tentang internet, 79,5\% memahami cara menggunakan internet, 20\% tidak menggunakan internet karena tidak memiliki alat digital untuk tersambung ke internet (Kompas 2014).

Selain fenomena yang dijelaskan sebelumnya, hasil wawancara dengan guru Bimbingan dan Konseling di MAN 1 Bengkulu Utara dinyatakan memang ada beberapa kasus dimana peserta didik menyalahgunakan penggunaan internet. Pada penelitian yang telah dilakukan sebelumnya lebih banyak membahas kecanduan game online pada remaja, tetapi pada penelitian kali ini lebih berfokus mengungkapkan sejauh mana pemahaman remaja dalam menggunakan internet, karena diharapkan dalam penggunaannya internet mampu memberikan efek positif bagi penggunanya. Pada dasarnya internet diharapkan bisa mendukung proses pembelajaran remaja, tetapi harus disadari juga bahwa internet itu seperti pisau bermata dua, memiliki sisi positif dan negatif, oleh karena itulah penelitian ini bertujuan untuk melihat sudah sejauh apa pemahaman remaja akan hal tersebut.

Hasil penelitian selanjutnya yang dilakukan UNICEF di Indonesia pada tahun 2012 dengan responden 400 remaja mengungkapkan 24\% remaja berhubungan dengan orang yang tidak dikenal melalui internet, $25 \%$ remaja memberitahukan alamat rumah dan nomor telepon secara bebas di internet, 52\% remaja menemukan konten pornografi melalui situs iklan di internet, $14 \%$ remaja telah mengakses situs porno, dan $25 \%$ sekolah negeri memberikan batasan kepada siswa terkait penggunaan internet, dan $45 \%$ sekolah swasta memberikan batasan kepada siswa dalam mengakses internet. Sangat penting bagi remaja untuk paham dalam menggunakan internet sehat (Rochim, Lilis et al. 2017). Pentingnya penelitian ini untuk memaksimalkan penggunaan positif dari internet serta meminimalisir hal-hal negatif yang bisa terjadi.

\section{METODE}

Artikel ini membahas berkaitan dengan pemahaman remaja tentang internet sehat di era globalisasi, jenis metode yang digunakan adalah literatur research dengan cara mengumpulkan teori-teori yang relevan, yang sama atau linear dengan topik yang dibaha Langkah-langkah penelitian yang pertama adalah mencari 
literatur yang relevan dengan topik yang dibahas, pada langkah kedua mencari gambaran (overview) topik penelitian yang akan dibahas, langkah ketiga yaitu mencari sumber penelitian baik dari berbagai macam literatur dan hasil penelitian yang ada. Langkah terakhir adalah mengumpulan sumber-sumber tersebut yang sudah didapatkan dan membuat gambaran maupun ringkasan.

\section{HASIL DAN PEMBAHASAN}

Masa remaja merupakan salah satu periode dalam rentangan kehidupan manusia. Periode remaja adalah periode di mana individu meninggalkan masa anak-anak dan mulai memasuki masa dewasa. Oleh karena itu periode remaja dapat dikatakan periode transisi dari masa anak-anak ke masa dewasa (Sari, Ilyas et al. 2017). Remaja (adolescence) adalah masa perkembangan transisi dari masa anak-anak ke masa dewasa awal, dimulai kira-kira usia 10-12 tahun dan berakhir usia 18-22 tahun (Santrock 2008). Ada tiga tahap perkembangan remaja, yaitu remaja awal usia 11-14 tahun, remaja perengahan usia 15-17 tahun, dan remaja akhir usia 18-20 tahun (Sarwono 2000). Remaja adalah Individu yang telah mengalami masa baligh atau telah berfungsi hormon-hormon reproduksi sehingga wanita mengalami menstruasi dan pria mengalami mimpi basah (Elida 2006).

Selanjutnya, remaja yang bahasa aslinya disebut adolescence, berasal dari bahasa latin yang artinya "tumbuh untuk mencapai kematangan". Bangsa primitif dan orang-orang purbakala menganggap anak sudah dewasa apabila sudah mampu mereproduksi (Asrori 2011). Dari berbagai pendapat ahli, pengertian masa remaja adalah masa transisi atau perubahan dari masa anak-anak menuju masa dewasa, yang rentangan usia mulai dari 10 sampai 21 tahun dan telah mengalami masa baligh yang ditandai dengan dua ciri utama yaitu menstruasi pada remaja wanita dan mimpi basah pada pria (Ahmad Susanto 2011).

Internet sehat merupakan gabungan 2 kata yang membentuk makna baru, internet merupakan jaringan komputer yang saling terhubung menggunakan standar sistem global Transmission Control Protocol/ Internet Protocol Suite (TCP/IP) yang bisa menghubungkan miliaran pengguna internet di seluruh dunia (Kaunang, Karim et al. 2021). Sedangkan sehat secara bahasa diartikan dengan baik seluruh badan dan bagian-bagiannya, mendatangkan kebaikan pada badan, sembuh dari sakit, baik dan normal (Rahardian 2011) .Ditafsirkan sebagai istilah untuk menjelaskan manfaat penggunaan internet, nilai positif dan produktif dari penggunaan internet bagi pengguna internet, keluarga dan masyarakat, sebaliknya apabila internet berdampak bahaya, bernilai negatif dan merugikan bagi pengguna internet, keluarga dan masyarakat maka hal tersebut dikatakan internet tidak sehat (RI 2010). Senada dengan itu, internet sehat adalah Memaksimalkan dampak positif yang ada di internet serta meminimalkan dampak negatif yang ada pada internet (Xlcare 2012).

Internet sehat bertujuan untuk hal yang baik, sesuai dengan norma, etika, agama, sebaliknya internet tidak sehat bertujuan untuk sesuatu yang buruk, seperti melanggar atau melawan hukum dan tidak sesuai dengan etika (Idris 2013).

Berdasarkan pendapat di atas, maka dapat disimpulkan bahwa internet sehat adalah istilah yang merujuk pada penggunaan internet yang bermanfaat, benilai positif, produktif, sesuai dengan norma yang berlaku, etika, dan agama yang bermanfaat untuk diri pengguna internet, keluarga, dan masyarakat.

Berikut ini penjelasan penggunaan internet sehat berdasarkan usia, agar manfaat internet dapat dimaksimalkan dan dampak negatif dapat diminimalisir. (Xlcare 2012) berikut ini penjelasan penggunaan internet sehat berdasarkan usia; (a) Usia 10-12 tahun, pada masa pra remaja, remaja sudah tepat dikenalkan tentang internet, internet berguna untuk membantu tugas sekolah ataupun menemukan hal-hal yang berkaitan dengan hobi remaja. Agar penggunaan internet bisa sehat dan positif, orang dewasa tetap harus memantau dan membatasi penggunaan internet, agar remaja bisa melakukan kegiatan lain, seperti berolahraga, membaca buku, dan bersosialisasi dengan teman. (b) Usia 12-14 tahun, pada masa ini remaja sudah memiliki ketertarikan dengan hubungan sosial, ketika menggunakan internet anak akan tertarik dengan chating, dan media sosial, pada masa ini harus ditekankan kepada remaja bahwa jangan sembarangan memberikan data 
pribadi kepada orang yang tidak dikenal, dan jangan melakukan pertemuan dengan orang yang baru dikenal, pada usia ini remaja harus memahami bahwa faktanya seseorang di internet bisa jadi tidaklah seperti yang dibayangkan atau digambarkan. (c) Usia 14-17 tahun, pada masa ini adalah masa yang paling menarik dan menantang dalam kehidupan seorang anak remaja, seorang remaja akan mulai matang secara fisik, emosi dan intelektual. Remaja haus akan pengalaman yang terbebas dari orang tua. Kehidupan remaja sangatlah rumit, sehingga remaja membutuhkan kebebasan sekaligus arahan pada waktu yang bersamaan. Remaja kerap melakukan hal-hal yang beresiko tinggi, baik online maupun offline. Remaja sering gegabah dalam mengambil keputusan untuk bertemu dengan seseorang yang baru dikenalnya melalui internet. Untuk itu agar remaja tidak terjebak dalam penggunaan internet tidak sehat harus ditanamkan dan ditekankan kepada remaja bahwa siapapun yang dikenal di internet belumlah tentu orang yang baik.

Penggunakan internet sehat berdasarkan usia; Pada usia 5-12 tahun (TK-SD), Pada masa ini anak-anak dan remaja awal diperkenalkan internet, pemahaman dasar terkait kelebihan dan kekurangan internet serta manfaat baik dan buruk internet juga harus ditanamkan kepada anak-anak dan remaja awal, orang tua dan guru tetap harus melakukan pengawasan. Selanjutnya pada usia 12-18 tahun (SLTP-SLTA), pada masa ini remaja eksplorasi besar-besaran terhadap dunia luar kehidupan keluarga. Pada masa pubertas remaja perlu mendapatkan arahan dan pendampingan yang tepat, agar tidak terjerumus kedalam kesengsaraan. Remaja yang sedang menggebu-gebu keinginan dan hasratnya, bertemu dengan internet yang menjanjikan serta menyediakan informasi segala hal yang mampu menjawab semua keingin tahuan remaja menjadikan internet dan remaja ibarat mesiu dan bom yang mudah meledak (RI 2010).

Penggunaan internet sehat berdasarkan usia merupakan hal yang harus dipahami oleh orang tua seperti guru dan orang tua, karena sikap dari remaja yang ingin bebas dan memiliki rasa ingin tahu yang sangat tinggi dan disana pengawasan orang tua dibutuhkan. Pada usia remaja menginjak SMP dan SMA tantangan menggunakan internet besar, hal yang berbahaya bisa muncul, seperti merencanakan pertemuan dengan orang yang baru dikenal merupakan hal yang sangat berbahaya, dengan mengetahui, dengan adanya pemahaman terkait penggunaan internet sehat diharapkan bisa mengurangi pertemuan remaja dengan orang yang baru dikenal di internet.

Untuk mewujudkan internet sehat dalam kehidupan sehari-hari adalah tanggung jawab semua pihak, mulai dari orang dewasa, orang tua, remaja, dan guru. Ada beberapa cara berinternet sehat, orang tua dan guru memiliki peran dalam menerapkan dan mengawasi internet sehat di rumah dan sekolah, apabila remaja berinternet sehat, guru mengawasi dan berinternet sehat di lingkungan sekolah serta orang tua menerapkan dan mengawasi remaja dalam berinternet di rumah, maka dapat meminimalisir internet tidak sehat dalam kehidupan (Ismail 2016).

Anggota Komite Regulasi Telekomunikasi pada Badan Regulasi Telekomunikasi Indonesia (BRTI) menyampaikan cara berinternet sehat a) tidak memberikan dan menyebarkan data pribadi (no hp, alamat rumah) kepada orang yang belum dikenal melalui internet, b) tidak mudah percaya dengan informasi yang tersebar luas di internet, c) bertanya kepada orang tua atau orang dewasa apabila ada informasi dari internet yang meragukan, d) menggunakan program filter agar terlindungi dari situs-situs pornografi, asusila, kekerasan, dan virus, e) selalu log out (keluar dari situs) setelah menggunakan media sosial (facebook, twitter, email,dll), f) menggunakan tata bahasa menulis yang sopan, santun, tidak menyakiti hati orang lain, dan tidak kasar, f) tidak melanggar hak cipta data milik orang lain seperti hasil foto, video, musik maupun hasil karya lainnya melalui internet, g) tidak melalukan penipuan, pemerasan, atau penghinaan serta pencemaran nama baik melalui internet, h) tidak menyebarkan informasi palsu (hoax), gambar dan video pornografi (Sukardi 2008).

Senada dengan pendapat sebelumnya, cara yang dapat dilakukan remaja untuk berinternet sehat yaitu menggunakan foto di media sosial yang sewajarnya, sopan santun dalam menggunakan media sosial, mempelajari sarana komunikasi dan kandungan informasi yang ditawarkan oleh Internet, secara bersama dengan orang dewasa. Apabila ada sesuatu hal yang tidak dimengerti oleh remaja terkait isi internet, ajukanlah 
pertanyaan kepada orang dewasa seperti orang tua. Dengan banyak bertanya, remaja bisa menggali sejauh mana mereka memahami Internet, juga tentang cara menggali informasi yang bermanfaat, sekaligus menjauhi informasi yang negatif, menjaga diri dari pertanyaan di private chat dari orang yang tak dikenal, termasuk tidak membuka file kiriman (attachment) dari orang yang tidak dikenal dan dalam bentuk apapun, saat mengisi informasi data diri di situs personal, blog ataupun situs lainnya di internet semisal (Sutadi 2012). MySpace.com ataupun Facebook.com, tinggalkan situs yang tidak baik, tidak pantas atau yang membuat remaja tidak nyaman, baik disengaja ataupun tidak sengaja terbuka, menceritakan kepada orang yang lebih dewasa tentang segala sesuatu yang ditemui di internet, tidak gegabah merencanakan pertemuan langsung (face-to-face) dengan seseorang yang baru mereka kenal di Internet.

Berinternet sehat di dalam keluarga juga harus diterapkan, karena keluarga merupakan pendidikan utama dan pertama bagi remaja. (Xlcare 2012) mengemukakan peran keluarga terutama orang tua dalam berinternet sehat di lingkungan rumah yaitu, meletakkan komputer di bagian rumah yang mudah dilihat bersama dan mudah dipantau, seperti di ruang keluarga, definisikan secara jelas dan gamblang aturan penggunaan internet di rumah. Kemudian tulis dan pasang aturan tersebut di tempat yang dapat dibaca oleh semua anggota keluarga, tidak melarang remaja mengakses internet, karena ketika dilarang remaja akan menggunakan internet secara sembunyi-sembunyi, tegaskan untuk tidak mendownload materi yang secara nyata merupakan materi ilegal, bajakan atau melanggar hak cipta, serta pornografi, tetaplah menjalin komunikasi yang baik dengan remaja, agar remaja mau terbuka atas hal-hal yang dilihatnya di internet, memasang software filter di rumah untuk menjaring situs-situs berbahaya di internet, periksa jejak situs web yang dikunjungi oleh remaja. Agar orang tua tahu situs apa yang dilihat oleh remaja di rumah, ajarkan anak bersikap sopan santun dalam berinternet.

Guru memiliki peran yang besar dalam menerapkan internet sehat di lingkungan sekolah., guru memegang peranan yang besar dalam mengajarkan perilaku ber-internet yang sehat kepada murid (Sutadi 2012). Guru merupakan orang tua kedua bagi murid, seorang guru memiliki peranan untuk memberikan perlindungan dan pengajaran kepada murid terkait internet sehat, terutama guru Bimbingan dan Konseling diharapkan mampu menerapkan perilaku yang baik. peran guru dalam internet sehat yaitu memberi pengertian kepada murid tentang fenomena internet, seperti manfaat dan dampak dari internet yang selama ini, apabila murid kedapatan memiliki atau saling berkirim konten porno via ponsel, segera hentikan tindakan murid tersebut dan jelaskan kepada murid bahwa memiliki atau menyebarkan konten seksual lewat ponsel merupakan pelanggaran hukum dan berisiko terhadap sesuatu yang tidak baik, melakukan razia isi ponsel murid secara berkala dari kelas ke kelas, terapkan kewajiban agar ponsel harus dititipkan di ruangan khusus dan tidak boleh dibawa ke kelas (Sutadi 2012).

Banyak cara yang dapat dilakukan untuk berinternet sehat seperti yang telah dijelaskan di atas, tetapi yang harus ditekankan bahwa semua pihak mulai dari orang tua, guru, dan remaja harus bersama-sama menerapkan internet sehat dalam kehidupan sehari-hari. Seperti mulai dari diri remaja membatasi waktu pemakaian internet, menceritakan kepada orang dewasa atau orang tua apabila ada sesutau yang tidak baik di internet, dan tidak bertemu dengan orang yang baru dikenal di dunia maya, selanjutnya dari lingkungan keluarga terutama orang tua yang hendaknya meletakkan komputer di ruangan yang dapat dipantau, tidak melarang anak menggunakan internet, dan bertanya kepada anak berupa bentuk perhatian tentang apa yang diakses remaja pada hari ini, selanjutnya dari lingkungan sekolah yang melakukan razia rutin hp yang dibawa siswa kesekolah (Sundari 2017).

Manfaat menggunakan internet sehat bagi remaja adalah a) remaja dapat belajar mengembangkan keterampilan teknis dan sosial yang sangat dibutuhkan di era digital, b) memperluas jaringan pertemanan, berkat situs jejaring sosial, remaja menjadi lebih mudah berteman dengan orang lain, tidak hanya bisa berteman dengan individu yang satu kota atau satu negara, tetapi juga bisa memiliki teman baru dari berbagai negara, c) remaja akan termotivasi untuk belajar mengembangkan diri melalui teman-teman yang dijumpai secara online, d) situs jejaring sosial membuat remaja menjadi lebih bersahabat, perhatian (Sasongko 2011). 
Senada dengan yang disampaikan sebelumnya, manfaat penggunaan internet sehat adalah a) sebagai media informasi, informasi yang tersedia seperti berita dari dalam dan luar negeri, berita surat kabar, informasi pendidikan sekolah dan lembaga pemerintahan, b) sebagai media komunikasi, internet memudahkan komunikasi jarak jauh, surat-menyurat, chatting \& video call, c) sebagai media belajar dan hiburan, di internet banyak tersedia sumber bahan pelajaran, informasi tentang sekolah, permainan menarik, menelusuri tempattempat wisata di berbagai dunia, berita olahraga, musik, film, d) sebagai media transaksi, jual beli barangbarang kebutuhan sehari-hari dapat dipesan melalui internet yang sering disebut online shop (Rahardian 2011).

Dari pendapat ahli sebelumnya, maka dapat disimpulkan bahwa manfaat penggunaan internet sehat itu banyak sekali, mulai dari individu mampu mengembangkan keterampilan teknis dan kemampuan sosial di era digital, hingga mampu menjadikan internet sebagai media transaksi jual beli yang banyak dilakukan oleh remaja saat ini. Remaja yang menggunakan internet sehat, akan merasakan manfaat-manfaat yang telah dijabarkan sebelumnya ketika menggunakan internet.

Ketika menggunakan internet hanya untuk hal-hal negatif dan bisa merugikan diri sendiri, keluarga, dan orang lain maka hal tersebut termasuk dalam penggunaan internet tidak sehat. Dampak negatif dari internet tidak sehat, diantaranya: a) kekerasan dan agresi internet dapat menciptakan pemahaman dan menumbuhkan sikap antisosial kepada remaja, b) pornografi, adanya keterkaitan antara terpaan adegan seksual (pornografi) di media terhadap cara berpikir remaja tentang seks dan keinginan melakukan hubungan seksual secara dini pada remaja, dan yang sangat berbahaya adalah gambar maupun video pornografi yang dilihat akan tertanam di otak remaja selamanya, c) gangguan belajar, remaja yang kecanduan dalam menggunakan internet berpotensi mengidap gangguan belajar yang disebut attention deficit disorder, d) efek kecanduan game online, berlama-lama mengakses game online. bermain game online di kalangan remaja menyebabkan efek ketagihan (candu) yang berdampak pada malas belajar, dan lupa waktu belajar sehingga prestasi belajar menurun, e) berkurangnya intensitas interaksi sosial off-line, penggunaan internet menyebabkan berkurangnya intensitas interaksi sosial di dunia off-line (Idris 2013).

Senada dengan yang disampaikan sebelumnya, dampak negatif dari penggunaan internet tidak sehat diantaranya: a) berkurangnya sikap sosial, kurang berminat untuk bergaul dengan lingkungan sekitar, jarang menghadiri pertemuan dengan orang lain, lebih memilih untuk sendiri dan menggunakan internet, b) merubah pola interaksi sosial, kurang menganggap penting tata krama, kurang menganggap penting arti persahabatan di sekolah, c) kecenderungan berbuat kejahatan, sering menemui perjudian di internet, pembobolan rekening dan pencurian kode rahasia merupakan hal yang biasa dilakukan melalui internet, d) kecanduan hal-hal negatif dari internet, seperti pornografi mudah ditemukan di internet dan membutuhkan biaya-biaya khusus untuk berlangganan permainan dan situs tertentu, seperti paket internet, voucher internet,dll (Rahardian 2011).

Dari pendapat para ahli-ahli sebelumnya, maka dapat disimpulkan bahwa dampak penggunaan internet tidak sehat sangat banyak, mulai dari munculnya sikap anti sosial, kecanduan bermain internet, hingga gangguan belajar, maka diharapkan remaja mampu dan paham menggunakan internet secara sehat, karena dampak dari penggunaan internet tidak sehat itu sangat banyak dan berbahaya. Diharapkan melalui studi ini bisa membuka mata orang-orang yang ada bahwa penggunaan internet pada remaja lebih baik disesuaikan dengan usia dan juga perlu adanya pengawasan dari orang dewasa yang ada di sekitar remaja, seperti orangtua dan guru. Pemahaman remaja tentang internet sehat harus ditingkatkan agar ditingkatkan lagi, sebagaimana hasil penelitian yang dilakukan pada tahun 2016 di kota Padang bahwa pemahaman remaja tentang internet sehat masih pada kategori cukup baik, hal ini masih bisa ditingkatkan lagi.

\section{KESIMPULAN}

Guru Bimbingan dan Konseling atau konselor di sekolah diharapkan lagi agar bisa menyusun program, atau materi layanan Bimbingan dan Konseling yang mampu meningkatkan pemahaman remaja tentang 
internet sehat, seperti layanan informal tentang pentingnya berinternet sehat dalam kehidupan sehari-hari, layanan orientasi tentang pengenalan internet kepada remaja, layanan bimbingan kelompok yang membahas topik-topik tugas terkait internet dikalangan remaja, dan yang terakhir melalui layanan penguasaan konten tentang cara berinternet sehat dalam kehidupan remaja atau cara memasang aplikasi filter pada smartphone. Guru Bimbingan dan Konseling atau konselor di sekolah diharapkan agar mampu memberikan layanan dengan cara yang baru, kreatif, menarik sehingga menarik perhatian remaja. Guru Bimbingan dan Konseling diharapkan mampu melakukan suatu inovasi baru, seperti membuat buku agenda internet, buku tersebut digunakan remaja untuk mencatat dari jam berapa saja remaja menggunakan internet dan apa saja yang remaja lakukan ketika menggunakan internet, misalnya untuk browsing, membaca buku pelajaran, media sosial. Satu langkah kreatif yang Guru Bimbingan dan Konseling bisa lakukan untuk meningkatkan pemahaman remaja tentang internet sehat adalah membuat poster yang ditempel di papan informasi sekolah.

\section{DAFTAR PUSTAKA}

Ahmad Susanto, M. P. (2011). Perkembangan anak usia dini: pengantar dalam berbagai aspeknya, Kencana.

Asrori, M. A. d. M. (2011). Psikologi Remaja: Perkembangan Peserta Didik. Jakarta, Bumi Aksara.

Elida (2006). Psikologi Perkembangan Remaja. Yogyakarta, Angkasa Raya.

Idris, K. d. M. (2013). "Dampak Fatologis-Non Fatologis Penggunaan Internet di Kalangan Anak dan Remaja." Jurnal komunikasi dan informatika 8: 4.

Ismail, M. (2016). "Studi Korelasi Implementasi Fiqh Parenting Terhadap Pola Internet Sehat Dalam Pendidikan Anak." At-Ta'dib 9(1).

Kaunang, F. J., A. Karim, et al. (2021). Konsep Teknologi Informasi, Yayasan Kita Menulis.

Kompas (2014). Hasil Survey Pemakaian Internet Remaja Indonesia.

Qomariyah, A. N. (2009). "Perilaku penggunaan internet pada kalangan remaja di perkotaan." Universitas Airlangga Surabaya 6: 55-64.

Rahardian, E. (2011). Pemanfaatan Internet dan Dampaknya Pada Pelajar SMA di Surabaya. Departemen Ilmu Informasi dan Perpustakaan Fakultas Ilmu Sosial dan Ilmu Politik Universitas Airlangga. Bachelor.

Rahayu, F. S. (2012). "Cyberbullying sebagai dampak negatif penggunaan teknologi informasi." Journal of Information Systems 8(1): 22-31.

Rahman, A. (2016). "Pengaruh negatif era teknologi informasi dan komunikasi pada remaja (perspektif pendidikan islam)." AL-ISHLAH: Jurnal Pendidikan Islam 14(1).

Ramdani, A. (2009). Strategi penentuan spot (titik) billboard iklan layanan masyarakat tentang spektrum frekuensi radio depkominfo di provinsi Banten tahun 2007-200, Universitas Mercu Buana.

RI, D. K. d. I. (2010). Internet Sehat. Garut, Sekretariat Daerah Kabupaten Garut Bagian Informatika.

Rochim, M., D. Lilis, et al. (2017). LAPORAN AKHIR PENGABDIAN KEPADA MASYARAKAT (PPI): PELATIHAN KOMPETENSI GURU BERWAWASAN MEDIA DI SEKOLAH ANGKASA BANDUNG, LEMBAGA PENELITIAN DAN PENGABDIAN PADA MASYARAKAT UNIVERSITAS ISLAM BANDUNG.

Santrock, J. W. (2008). Adolescence (Perkembangan Remaja). Jakarta. e.

Sari, A. P., A. Ilyas, et al. (2017). "Tingkat kecanduan internet pada remaja awal." JPPI (Jurnal Penelitian Pendidikan Indonesia) 3(2): 110-117.

Sarwono, S. (2000). Psikologi Remaja. Jakarta, Rineka Cipta.

Sasongko, A. (2011). Internet Sehat. Jakarta, ICT Watch. 
1066 Pemahaman Remaja Tentang Internet Sehat di Era Globalisasi - Dian Montanesa, Yeni Karneli DOI: https://doi.org/10.31004/edukatif.v3i3.509

Simangunsong, J. (2015). "Penyalahgunaan Narkoba Di Kalangan Remaja (Studi kasus pada Badan Narkotika Nasional Kota Tanjungpinang)." Program Studi Ilmu SosiologiFakultas Ilmu Sosial Dan PolitikUniversitas Maritim Raja Ali Haji Tanjungpinang.(E-journal) http://hukum. Studentjournal. ub. ac. id (di akses pada 20.

Sukardi (2008). Evaluasi Pendidikan (Prinsip dan Operasionalnya). Jakarta, Bumi Aksara.

Sundari, F. (2017). "Peran Guru Sebagai Pembelajar dalam Memotivasi Peserta Didik Usia SD."

Sutadi, H. (2012). Cara Menggunakan Internet Sehat. http://filmpelajar.com/page/14-cara-menggunakaninternet-secara-sehat. 2015.

Widayani, S. and K. Astuti (2020). "Pembentukan Karakter Melalui Pola Asuh Demokratis Untuk Mencegah Kecanduan Gadget Remaja Di Era Revolusi Industri 4.0." Psycho Idea 18(1): 74-81.

Xlcare (2012). Internet Sehat. Jakarta, ICT Watch. 